\title{
DIE HELIKOPTER AS TROEPEDRAER IN KONVENSIONELE LUGOPERASIES
}

KMDT C. J. NÖTHLING*

\begin{abstract}
Helicopter deployment has become an integral and vital component of armies, air forces and navies throughout the world. In terms of operational use, the modern helicopter can be employed in a diversity of roles on the battlefield, inter alia as an assault weapon, a transport medium for airborne operations and in a logistical capacity. The author examines and evaluates the aspect of airborne deployment with specific reference to conventional helicopterborne assault operations. The analysis is based upon the basic and secondary principles of offensive (ground) warfare, viz mobility, logistic support, the exploitation of supporting fire and the rapid concentration of force. However, a principle which specifically applies to the use of airborne assault units, is vertical development. Contending that the transport helicopter is an excellent and viable Blitzkrieg vehicle, the author concludes that it is a most effective 'weapon'. But just like any other offensive unit, it has to be deployed in combination with other weapon systems (armour, artillery, and infantry) to realize its full potential. His argument that the days of the paratrooper are numbered and that he should be replaced by the 'helitroop', is controversial but interesting.
\end{abstract}

\section{Inleiding}

Helikoptereenhede maak vandag integrerende en haas onmisbare komponente van die gevegsdienste (grond-, lug- en vlootmagte) van lande dwarsoor die wêreld uit. In die scenario van moderne oorlogvoering is die helikopter 'n essensiële element, hetsy as aanvalswapen in teeninsurgensiewe optredes of as blote logistieke voertuig vir die ontplooiing en konsentrasie van troepe op die konvensionele slagveld. In terme van operasionele aanwending vul die moderne helikopter ' $n$ veelsydige spektrum van alternatiewe waarvan veral drie as resente ontwikkelinge beskou kan word, $\mathrm{nl}$ (a) die aanvalswapen (gevegshelikopter), (b) tenkafweer en (c) lugoperasies. $^{1}$

Ofskoon die gevegshelikopter veral tov sy aanwending in 'n tenkafweerrol tans voorkeur geniet in die militêre ontwikkelingsprogramme van NAVO en die Warskouverdragslande met die oog op konvensionele aanwending, is die vraghelikopter as operasionele vervoermiddel nie minder belangrik nie. ${ }^{2}$ Trouens, as in aanmerking geneem word dat gewapende konflik in die huidige tydsgewrig oorwegend ' $n$ onkonvensionele karakter vertoon waarvan revolusionêre bedrywighede ' $n$ element uitmaak, lê die aktualiteit van die vraghelikopter as veral troepedraer voor die hand. In hierdie artikel word sy rol egter slegs tov konvensionele operasies bespreek.

In hierdie artikel gaan die skrywer van die standpunt uit dat die lesse wat gedurende die oorloë in Korea en Viëtnam geleer is, veelal negeer word en nie genoegsaam toegepas word in die beplanning en bedryf van operasies deur paramilitêre magte nie. In samehang hiermee sal by wyse van historiese analise aangetoon word dat die 'helitroep' in feitlik alle opsigte ' $n$ doeltreffende alternatief daarstel vir die konvensionele valskermsoldaat wat ongeag sy heroïese assosiasie met opwindende operasies in die verlede, in die algemeen nooit werklik aan die vereistes van vertikale omsingeling en snelle ontplooiing voldoen het nie. ${ }^{3}$

Volledigheidshalwe word die evolusie van die helikopter as lugvervoermiddel ter inleiding in 'n historiese perspektief geplaas.

\section{Ontstaan en ontwikkeling}

Die oorsprong van die helikopter kan so ver teruggevoer word as die vlieënde speelgoedtolle van die antieke Chinese beskawing (400 VC), dog binne die raamwerk van die Westerse lugvaartkunde is die herkoms en verwesenliking van beheerde vertikale vlug betreklik resent. Hoewel die helikopter se ontwikkeling feitlik parallel met dié van die vastevlerkvliegtuig verloop het, was die velerlei tegniese probleme wat verband hou met die sg 'spirale vlerk' daarvoor verantwoordelik dat die vervolmaking van die helikopter langsamer plaasgevind het. Onderwyl vliegtuie gedurende die Eerste Wêreldoorlog ' $n$ belangrike ondersteunende rol gespeel het, het ontwerpers soos Theodore von Karman steeds geworstel met die probleem van vertikale opstyging. ${ }^{4}$ Volgens Franklin Gregory is die taktiese moontlikhede van 


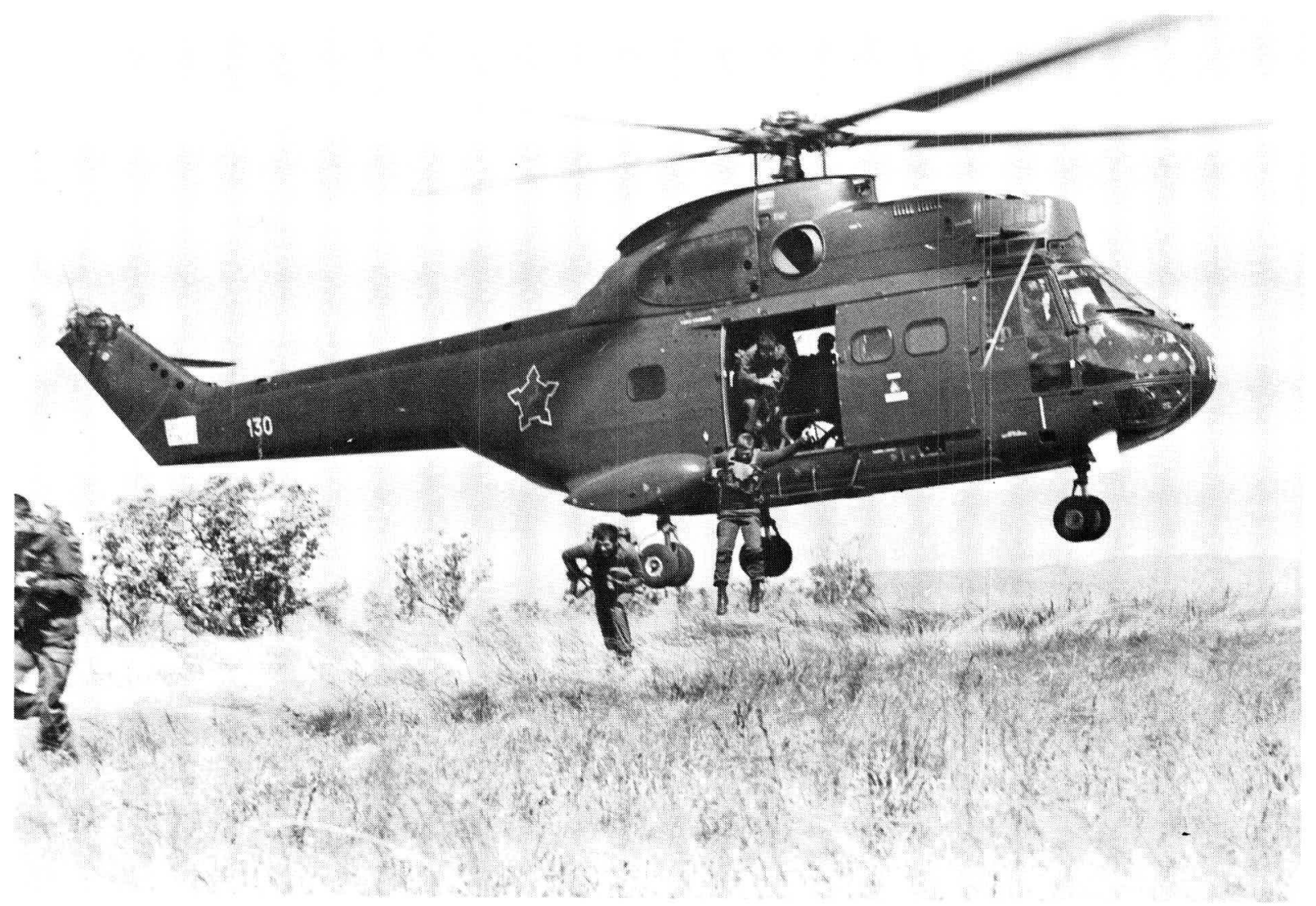

Puma helikopter besig om troepe af te laai in die veld.

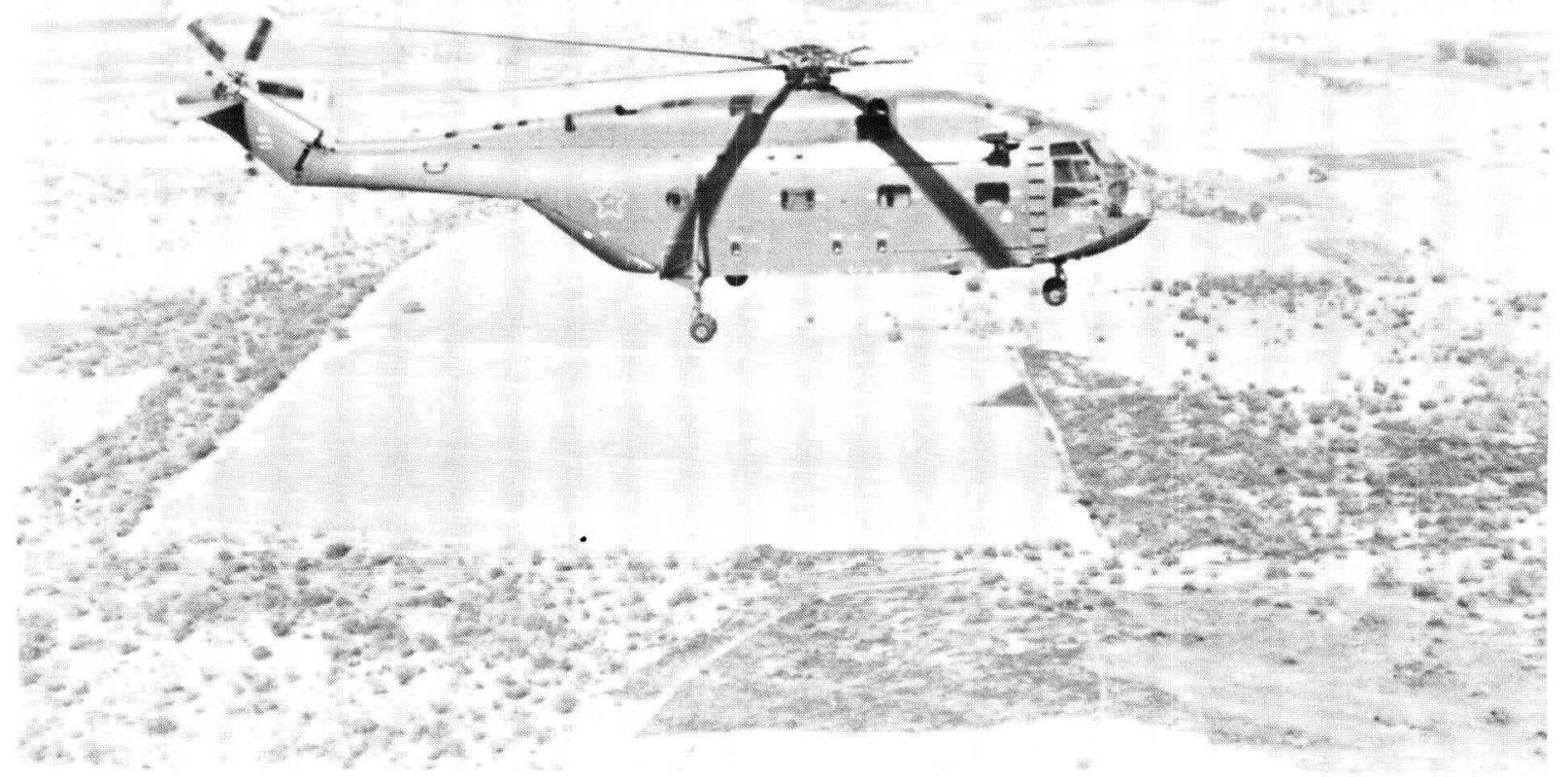

Die Super Frelon helikopter wat ook as troepedraer aangewend kan word. 
die helikopter slegs in terme van verkenning oorweeg: 'It was practically forgotten except that strategists on both sides thought of a machine that could hover in the sky over the enemy and spot his movements.' 5

Hoewel die rotasie- en torsieprobleme wat die verdere ontwikkeling van die helikopter aan bande gelê het by die aanbreek van die Tweede Wêreldoorlog reeds in 'n groot mate oorbrug is, het dit gedurende dié konflik 'n onbelangrike rol in krygsoperasies gespeel. In hierdie opsig het Duitsland aanvanklik die voortou geneem met die uiters betroubare FT 282 Kolibri, wat hoofsaaklik verkenningsvlugte vanaf skepe onderneem het. Die Geallieerde moondhede het veral staatgemaak op die Amerikaanse R-4 Sikorsky wat hoofsaaklik in seereddingsoperasies gebruik is.

Helikopters is egter ook aangewend om die bemannings van vliegtuie wat agter die vyandelike linies noodlandings moes doen, uit te lig. Afgesien hiervan was die militêre helikopter in die vroeë veertigerjare ten beste ' $n$ interessante 'lugvaartfrats' waarvan die taktiese aanwending haas geen oorweging geniet het nie. ${ }^{6}$

Voor die Koreaanse oorlog het die Amerikaanse Lugmag die helikopter hoofsaaklik gesien as 'n voertuig vir lugreddingswerk. Gedurende hierdie konflik is dit dan ook aanvanklik in 'n reddings- en verkenningsrol aangewend maar sedert 1951 is die helikopters ook met welslae vir die afvoer van oorlogsongevalle gebruik. ${ }^{7}$ Dit het egter algaande duidelik geword dat die helikopter 'n belangrike plaasvervangende rol kon speel wat betref die vervoer en aflaat van troepe en voorrade.

Die voordele verbonde aan vertikale aanvulling (d.i. die gebruik van helikopters om ammunisie en voorrade ter see tussen skepe en landwaarts te vervoer) is terdeë deur die VSA se amfibiese mariniersmagte ingesien; ${ }^{8}$ tydens twee operasies in September 1951 is vraghelikopters gebruik om 'n bataljon seesoldate en 9 ton voorraad na 'n afgeleë stelling in vyandelike gebied te neem. ${ }^{9}$ Die Amerikaanse Leër het ook vrylik van helikopters gebruik gemaak vir troepeverskuiwings en ofskoon meer as 2000 missievlugte onderneem is, is slegs een helikopter deur vyandelike vuur afgebring.

Ná die beëindiging van die Koreaanse oorlog het Amerikaanse opvattinge oor die helikopter gesentreer om die moontlikhede wat dit as 'n logistiese vervoermiddel sou inhou. In dié verband is selfs voorspel dat helikopters binne 5 jaar gebruik sou word vir die vervoer van 80 persent van die Leër se troepe en krygsvoorrade.

Gedurende die oorlog in Viëtnam het die helikopter 'n prominente rol in operasies gespeel nie alleen tov sy tradisionele rol as vervoermiddel nie maar ook as 'n aanvalswapen. 'n Groter mate van diversifikasie het plaasgevind ten einde die veeldoelige aanwending van die helikopter moontlik te maak. Mettertyd het 'n aksentverskuiwing in die rigting van die gevegsrol plaasgevind en in resente literatuur word heelwat aandag aan die taktiese gebruik van die 'tenkafweerhelikopter' gegee.

In die voorgaande oorsig is die geskiedenis van die militêre helikopter breedweg geskets. Die doel van dié oorsig was uitsluitlik om die verskillende aspekte van lugvervoer enigsins te belig en nie om 'n volledige kroniek daar te stel nie. Wat die aanwending van helikopters ter bekamping van terrorisme en verwante vorme van onkonvensionele oorlogvoering betref, word die ontwikkelingsgeskiedenis nie as sodanig hier behandel nie. In hierdie verband is gepoog om die 'historiese' aspekte slegs waar dit ter sprake kom op 'n geïntegreerde grondslag toe te lig.

\section{Operasionele doeltreffendheid volgens die beginsels van offensiewe oorlog- voering}

Veelal word operasionele doeltreffendheid op ' $n$ hoogs indirekte wyse dmv slegs een norm bepaal, nl die verwesenliking van die gestelde doel. Die grootste beswaar wat teen dié metode van evaluering ingebring kan word, is dat die samestellende elemente in die proses van aanwending nie elk afsonderlik en regstreeks geëvalueer word nie. Hierbenewens moet kennis geneem word van die feit dat die korrelatiewe verband tussen doel en resultaat nie noodwendig 'n reële toedrag van sake weerspieël nie. Só byvoorbeeld het sommige skrywers bloot op grond van die waarneming dat die gebruik van helikopters in regstreekse aanvalle op terroristebasisse nie effektief is nie, die helikopter as ' $n$ nuttelose wapen in teeninsurgensie-operasies bestempel. ${ }^{10}$ In hierdie geval is dit doeltreffendheid wat ter sprake kom, dws die verkreë resultate moet geïnterpreteer word op grond van die vereistes van voorgeskrewe aanwending wat in militêre terme neerkom op aspekte soos taktiek, strategie en doktrine. Omdat hierdie veranderlikes enige metingsproses in 'n gegewe situasie sal beïnvloed, is dit belangrik dat die metingskriteria konstant sal wees ongeag die 
militêre situasie op ' $n$ bepaalde tydstip. In hierdie verband moet egter rekening gehou word met die onderskeid tussen offensiewe en defensiewe operasies wat sekere afwykinge ten opsigte van die kriteria vir elk van hierdie wyses van oorlogvoering (kan) impliseer.

Aangesien operasies by wyse van nabetragting in die reël volgens die voorgeskrewe beginsels van bedryf ontleed word, gaan die skrywer uit van die aanname dat hierdie beginsels as uiters relevante kriteria gebruik kan word. In aansluiting hierby word aanvaar dat die beginsels wat vir oorlogvoering op die grond geld, ook van toepassing is op die ontplooiing van lugvervoerde troepe. Die algemene beginsels of kriteria ter sprake sluit in mobiliteit, logistiese ondersteuning, die benutting van ondersteunende vuur, verrassing, die ekonomiese aanwending van magte, omsingeling, spoed en die konsentrasie van mag. ${ }^{11}$ In offensiewe oorlogvoering kan verder bepaalde prinsipes van aanwending onderskei word, $\mathrm{nl}$ die keuse van maneuver, die draaibeweging ('n aanvullende prinsipe tot omsingeling), penetrasie as ' $n$ voortsetting van die konsentrasie van mag, frontale aanval en agtervolging. Wat defensiewe operasies betref, kan verdediging in diepte en die herontplooiing as bykomende beginsels beskou word. In hierdie artikel word uitsluitlik gelet op operasies van offensiewe aard.

\section{Offensiewe Operasies}

Indien die aspek van mobiliteit in die gebruik van helikopters vir offensiewe operasies in aanmerking geneem word, kan eerstens gewys word op die uitskakeling van beperkinge wat tyd en ruimte op die aanvalsmag lê. Wanneer troepe per

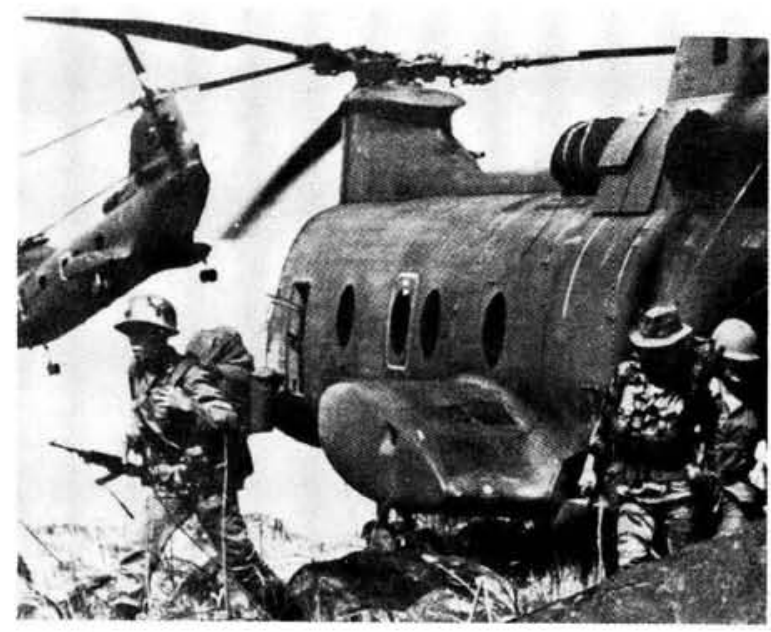

Amerikaanse infanteriesoldate ontskeep vanuit 'n tweemotorige Boeing-Vertol $\mathrm{CH}-46$ helikopter.

(Foto: Joan Bradbrook, 'The World's Helicopters,' 1972) helikopter na afmarspunte vervoer word, is die tydsverloop aansienlik korter as in die geval van grondvoertuie. Nie alleen kan die lugvervoerde soldaat langs die kortste moontlike roete na sy bestemming geneem word nie, maar sy mobiliteit word verder verhoog deur die afwesigheid van ruimtelike faktore wat die mobiliteit op die grond aan bande lê, bv natuurlike hindernisse (riviere, berge ens) en vyandelike struikelblokke, bv mynvelde, fronte en linies, blokhuise en bemande versperrings. Voorts het die lugvervoerde mag nie te kampe met die verkeersprobleme wat op belangrike hoofroetes ondervind word nie. Die lugvervoerde mag kan agv verhoogde mobiliteit belangrike doelwitte agter die vyandelike linies vernietig of beset. ${ }^{12}$ Tydens die Joem Kippoeroorlog (1973) het Arabiese 'helitroepe' daarin geslaag om tydelik beheer te verkry oor die strategiese bergpasse wat toegang tot die Sinaï verleen; hoewel hierdie voorste element later nie die druk van Israelse eenhede op beide kante van die bergpasse kon weerstaan nie, is hierdie operasie met redelike welslae uitgevoer en was hul mislukking grotendeels te wyte aan die onvermoë van die Egiptiese hoofmag om deur te breek.

Operasionele doeltreffendheid ten opsigte van die aspek van logistiese ondersteuning kan ook in terme van tyd- en ruimtelike faktore beoordeel word. In hierdie verband dien dit gemeld te word dat logistiese ondersteuning via die lugkanaal in soortgelyke omstandighede as in die geval van mobiliteit bevoordeel word. Nietemin moet toegegee word dat die transporthelikopter ten opsigte van drakrag aan beperkinge onderhewig is: in die huidige tydsgewrig speel dit nog ' $n$ komplementêre rol naas groot transportvliegtuie soos o.a. die Lockheed C-5A Galaxy wat vir die vervoer van tenks en artilleriegeskut gebruik kan word. ${ }^{13}$ Maar die welslae met die eerste generasie supervraghelikopters soos die Sikorsky Skycrane en die $\mathrm{CH}-47$ Chinook in Viëtnam behaal, dui daarop dat die transporthelikopter van die toekoms selfs 'n primêre logistiese rol kan speel. ${ }^{14}$ Hierdie tipes asmede die Russiese YAK-24 is ontwikkel met die oog op die aanvoer van hoofkrygstuig soos sagtevelvoertuie en kanonne. Die toenemende rol wat helikopters in logistieke aanvoering speel, blyk uit die feit dat helikopters gebruik is vir die aanvoer van 55 persent van Amerikaanse oorlogsvoorrade wat in die tydperk 1967-1969 per lug in Viëtnam vervoer is. ${ }^{15}$

Die operasionele doeltreffendheid van die helikopter tov logistiese ondersteuning word verder 

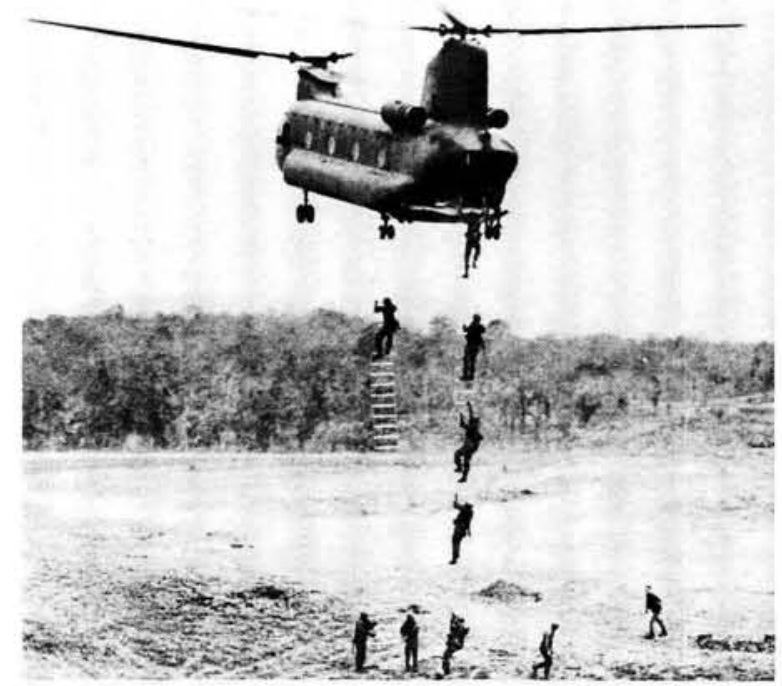

Troepe van die VSA Leër se '1st Cavalry Division' (Lugmobiel) verlaat 'n stilhangende $\mathrm{CH}-47$ Chinookhelikopter dmv 'n touleer.

(Foto: Norman Polmar en F.D. Kennedy, 'Military Helicopter of the World,' 1981)

verhoog deur die regstreekse en akkurate lewering van voorrade en krygsbehoeftes op die grond. Dit beteken dat verlangde items presies afgelewer word op lokaliteite soos deur die taakmag op die grond verlang. Die beperkinge waaraan konvensionele transportvliegtuie in hierdie opsig onderhewig is, soos bv ' $n$ gebrek aan landingsgeriewe wat lewering vanuit die lug bemoeilik, word hierdeur uitgeskakel. ${ }^{16}$

Die benutting van ondersteunende vuur is 'n prinsipe wat hoofsaaklik met grondsteunvuur vanuit die lug (vegvliegtuie en subsoniese bomwerpers) in verband gebring word. Ofskoon die verlening van noue grondsteunvuur streng gesproke nie binne die operasionele raamwerk van die transporthelikopter val nie, kan volledigheidshalwe gewys word op die aanwending van gewapende helikopters (helikopters met boordbewapening) in Viëtnam om dekkingsvuur aan 'n lugvervoerde taakmag te verleen. In 'n teikengebied waar vyandelike lugafweerstelsels besonder effektief kan wees, is hierdie sogenaamde 'gunships' feitlik onontbeerlik tydens die landing en opstyging van'die transporthelikopter(s). ${ }^{17} \mathrm{Die}$ feit dat die transporthelikopter self nie oor voldoende boordbewapening beskik nie, beklemtoon egter sy eie kwesbaarheid in veral kritieke stadia van 'n operasie, dws net voor landing en tydens opstyging.

Die ekonomiese aanwending van beskikbare mannekrag in ' $n$ operasionele sin dui nie bloot op 'n kwantitatiewe proses nie maar ook op funksionele gebruik. In hierdie verband kan die ekonomiese aanwendbaarheid van die transporthelikopter gesien word teen die agtergrond van die take en operasies waarvoor dit gebruik kan word. Wat laasgenoemde betref, kan die helikopter aangewend word vir verskillende operasies, o.a. bergoperasies, rivierkruisings, strooptogte deur kommandogroepe, woestynoperasies, ens.

Op taktiese vlak leen die helikopter hom tot die ekonomiese toewysing van mannekrag en materiaal volgens die heersende behoefte(s) van die hoofmag. Die posisie van 'n divisie of brigade wat oor ' $n$ wye gebied ontplooi is kan van plek tot plek verskil afhangende van die verloop van die geveg in daardie lokaliteite. Waar tekorte ontstaan kan aanvulling dmv helikopters gedoen word en kan die reële verspreiding en ontplooiing van troepe relatief ongehinderd plaasvind.

Die beginsel van omsingeling, wat uiteraard op offensiewe oorlogvoering van toepassing is, hang ten nouste saam met die vereistes van mobiliteit en verrassing. In fisiese terme berus dit egter veral op ruimtelike faktore, o.a. terrein en vervoermiddele. Tradisioneel moes die omsingeling van vyandelike magte geskied dmv grondmaneuvers maar sedert die Tweede Wêreldoorlog word daar ook van omsluiting via die lug (vertikale ontplooiing) gebruik gemaak. Die transporthelikopter leen hom in ' $n$ hoë mate hiertoe veral ten opsigte van statiese teikens soos bv vyandelike basisse en kleiner enklawes van verset. Dit kan ook doeltreffend aangewend word in die opsporing en uitwissing van partisane groepe soos in bv hakkejagoperasies.

Die welslae wat die Amerikaanse magte en veral eenhede van die VSA Marinekorps met omsingelingsmaneuvers behaal het, hou grootliks verband met die feit dat die ontplooiing van die aanvalsmag driedimensioneel in die lug kan plaasvind. Die omsingelingsmag kan danksy hoër mobiliteit en spoed vinniger as die vyand op die grond beweeg wat beteken dat dit nie nodig is om elemente van die vyand onder vuur te neem voor die hoofaanval nie. ${ }^{18}$

Dit dien gemeld te word dat die beginsel van verrassing in die omsingelings- en draaimaneuver ' $n$ uiters belangrike rol speel. Die voordeel wat voortspruit uit die aanwending van 'helitroepe' in dié maneuver is $\mathrm{nl}$ dat die draaibeweging grondwaarts vergemaklik word. Omdat die 'helitroepe' in die uitvoer van 'n draaibeweging hul aanvanklik buite die ondersteuningsvuur van ander aanvalselemente bevind, moet aanvals- 
planne voorsiening maak vir maksimum lugsteun en vroeë aansluiting met ander magte.

Ofskoon die konsentrasie van mag normaalweg met die aanwending van pantser oor 'n smal front met die oog op penetrasie in verband gebring word, kan die helikopter in dié opsig ' $n$ bydraende rol speel. Aangesien die oogmerke van dié beginsel slegs verwesenlik kan word indien 'n plaaslike oormag in die sektor van beplande deurbraak bestaan, word die sukses daarvan grootliks bepaal deur die tempo van magsopbou en die maskering van ontplooiingsmaneuvers. Die rede hiervoor is dat die vyandelike magte onmiddellik sal optree om die magsewewig in beoogde deurbraaksektore te herstel. Derhalwe moet die magsopbou in konsentrasiepunte snel verloop ten einde die tydsverloop voor D-dag tot ' $n$ minimum te beperk. Deur die aanwending van helikopters kan infanterie- en ondersteuningselemente wat die pantserkomponent vergesel, kort voor $\mathrm{H}$-uur na afmarspunte ingevlieg word.

Die helikopter kan ook ' $n$ belangrike rol speel in taktiese maneuvers wat tydens die geveg 'n plaaslike oormag op bepaalde lokaliteite vereis. Dit is veral toepaslik waar die beginsel van penetrasie direk voortvloei uit die konsentrasie van mag.

Die prinsipe van verrassing word allerweë deur taktiese beplanners as die belangrikste faktor in beperkte operasies beskou. Operasionele doeltreffendheid in hierdie opsig word in 'n groot mate bepaal deur aspekte soos inligting, sekerheid, mobiliteit en spoed. Die verrassingsaspek is dus grotendeels gebaseer op die toepassing van die beginsels wat in die voorgaande gedeelte bespreek is. By wyse van afleiding kan dit dus gestel word dat die helikopter se welslae tov die beginsel van verrassing tot op 'n groot hoogte deur hierdie beginsels bepaal word. Só bv kan die skielike invoer van troepe (dws volgens die beginsels van mobiliteit en spoed) na 'n afmarspunt met die konsentrasie van mag en penetrasie as doel, tot verrassing bydra. Die verrassingsaspek blyk ook uit die doeltreffendheid van die helikopter in spesiale operasies.

Die keuse van die maneuver word bepaal deur verskeie faktore, o.a. die direktiewe van die opperbevel, terreingesteldheid, die relatiewe posisie tov die strydende magte se ontplooiing en beskikbare vuursteun. Die moontlikhede wat die helikopter bied, beteken dat die opperbevel 'n wyer keuse van alternatiewes het en aan die maneuver 'n groter mate van buigsaamheid verleen word. Ten opsigte van 'n faktor soos terreingesteldheid word die bevelvoerders nie aan bande gelê deur natuurlike en selfs vyandelike struikelblokke (bv mynvelde) nie. Terselfdertyd kan die relatiewe posisie tov ontplooiing uitgebuit word omdat die eie magte reeds in die lug begin ontplooi. Hoewel probleemsituasies kan ontstaan wat vuursteun betref, is reeds gewys op die rol wat aanvalshelikopters kan speel in die lewering van lugdekking. ${ }^{19}$

Die frontale aanval impliseer ' $n$ aanval in die konteks van geïdentifiseerde fronte (eie en vyandelike magte) waar geografiese faktore (topografie, ens) geen ander alternatief bied nie. In die frontale aanval is die helikopter se hooftaak die vervoer van troepe en voorrade na versamelen afmarspunte asmede die indra van reserwemagte en voorrade tydens die geveg. Die transporthelikopter kan egter ook doeltreffend aangewend word in sekere operasies wat soms die frontale aanval insluit soos bv amfibiese operasies. Tradisioneel moes seesoldate met behulp van landingsvaartuie poog om die strandgebied te bereik. Afgesien van die relatief hoë verliese wat gedurende die naderingsfase gely word, kan die invalsmag vir 'n onbepaalde tydsduur deur die vyandelike kusverdediging in die oop strandgebied vasgepen word. Deur gebruik te maak van helikopters, kan die voorste echelon van die invalsmag ' $n$ brughoof agter die vyandelike kusverdediging skep.

\section{Die helikopter as plaasvervanger vir die valskermsoldaat}

Ten einde die 'helitroep' in ' $n$ plaasvervangende rol mbt valskermoperasies te konsipieer, word dit nodig geag om in die eerste plek die doeltreffendheid van valskermoperasies vlugtig in oënskou te neem en by wyse van hipotese die 'helitroep' as plaasvervanger in bepaalde operasies te vergelyk en te evalueer. Vir dié doel word enkele studiegevalle ontleed en bespreek.

Sekerlik een van die belangrikste operasies waarby valskermtroepe gedurende die Tweede Wêreldoorlog betrokke was, was die slag van Arnhem. Die Geallieerde valskermkomponent, wat bestaan het uit 3 valskerm- en een sweefvlugbrigades, het opdrag gehad om volgens die beginsel van vertikale omsingeling die gebied om die dorp te beset.

In die uitvoering van dié deel van die operasie het die Geallieerde magte vanweë die terreingesteld- 
heid van die gebied heelwat landingsprobleme ondervind. Benewens die Rynrivier, wat die vernaamste belemmeringsfaktor uitgemaak het, was die area deurspek met gragte en afleivore terwyl die grond in sekere gedeeltes van die landingsones te sag was vir sweeftuiglandings. Vanweë ' $n$ wisselende windsterkte is baie sweeftuie tussen bome vernietig terwyl 'n groot aantal valskermsoldate nie in hul bestemde sones afgelaat is nie. Maar die grootste struikelblokke was vyandelike lugafweer, 'n gebrek aan versterkings, ammunisie en grondsteunvuur en die bykomende las van gewondes op hul makkers se skouers. Toe die operasie gefaal het, is die invalsmag (of wat daarvan oorgebly het) aan sy eie lot oorgelaat. ${ }^{20}$ Die omsingelingsmag is uiteindelik self omsingel en vernietig. Hoe sou 'helitroepe' in die omstandighede van Arnhem in 1944 gevaar het? Ofskoon enige antwoord hierop uiters spekulatief is, kan nietemin bepaalde aannames gemaak word. Eerstens sou die gebruik van helikopters die belemmering van terreingesteldheid in 'n groot mate uitskakel wat akkurater en kleiner verliese sou verseker. Wat die vyandelike lugafweer betref moet argumentshalwe aanvaar word dat 'helitroepe' ook nie oor noue grondsteun sou beskik nie: in sodanige geval is die helikopters meer kwesbaar as die transportvliegtuig, dog verliese kan laer wees omdat die troepe buite die skootsveld van die vyandelike lugafweer afgelaat word op versamelingspunte waarvandaan verder ontplooi word. In die moderne konteks sal 'helitroepe' egter die nodige grondsteun van aanvalshelikopters geniet. Inmiddels word bystandshelikopters gebruik vir die afvoer van dooies en gewondes wat die omsingelingsmag op die grond vrystel vir hul taak.

Sou die 'helitroepe' van Arnhem ook in hul missie faal, en sou die omsingelingsmag ook op homself aangewese wees om uit die verknorsing te kom, kon hulle staatmaak op die helikopters om hulle weer uit te lig na veiligheid.

Ondanks die beskeie welslae wat met valskermoperasies gedurende Operasie Overlord in Normandië behaal is, het soortgelyke probleme opgeduik. Spronge was onakkuraat en verspreid terwyl sweefvliegtuie teen die omheinings van landerye verpletter is. Sommige soldate is tot $30 \mathrm{~km}$ van hul bestemde sones afgelaat en baie het in die Merdethrivier en die omliggende moerasse beland en verdrink. In een besondere geval het die bevelvoerder aan die oostekant van die rivier geland terwyl sy regiment hulle aan die westelike oewer bevind het. Van die Britse divisie, wat sowat 6000 man sterk was, is 821 gedood, 2709 ernstig gewond en 927 as vermis aangegee - ' $n$ ongevallesyfer van bykans 75 persent. ${ }^{21}$

Gedurende die Tweede Wêreldoorlog het die Duitse Fallschirmjäger aanvanklik asemrowende suksesse behaal in Nederland, Noorweë en België. Maar soos latere operasies soos o.a. in Kreta bewys het, was die valskermsoldaat wat konvensionele oorlogvoering betref, op die weg van verganklikheid. Soos Adolf Hitler tereg verklaar het, was die welslae wat wel behaal is, grootliks aan die element van verrassing te danke:

'The parachute arm is one that relies entirely on surprise. That surprise factor has now exhausted itself. The day of paratroops is over.'22

Maar sou die 'helitroep' in sodanige toestande enigsins beter kon vaar? In die Viëtnamese konflik is bevind dat oor korter afstande die 'helitroep' ' $n$ beter keuse is. Waar operasies oor relatief groot afstande uitgevoer moet word, kan die helikopter egter nie met die transportvliegtuig tov vliegafstand en dravermoë meeding nie. In sulke gevalle is valskermoperasies die enigste alternatief. ${ }^{23}$

Dit is interessant om daarop te let dat beide die Amerikaanse en Russiese militêre taktici die helikopter as die aangewese voertuig vir operasies wat hoë lugmobiliteit vereis, beskou. In teenstelling met die Amerikaners, verwerp die Russe die konsep van lugaanvalle op divisievlak; volgens die Russiese beskouing moet die gemeganiseerde geweerbataljon in staat wees om dmv helikopters as voorhoede vir die pantserkolonne te opereer.

\section{Voordele en nadele}

Soos dit uit die voorgaande blyk, kan die helikopter doeltreffend binne die raamwerk van konvensionele offensiewe operasies aangewend word. Sy vertikale landingsvermoë verseker akkurate aflating en ontplooiing sowel as die uitligting van troepe ná ' $n$ operasie. Die belemmeringe wat terreinfaktore op vastevlerkvliegtuie plaas, word grotendeels uitgeskakel.

In teenstelling met die valskermsoldaat, wat 'n gespesialiseerde opleidingsprogram moet deurloop, word van die 'helitroep' feitlik geen spesiale opleiding vereis nie. ${ }^{24}$

Voorts moet daarop gelet word dat aan taktiese landingsmagte verskillende missies opgedra kan 


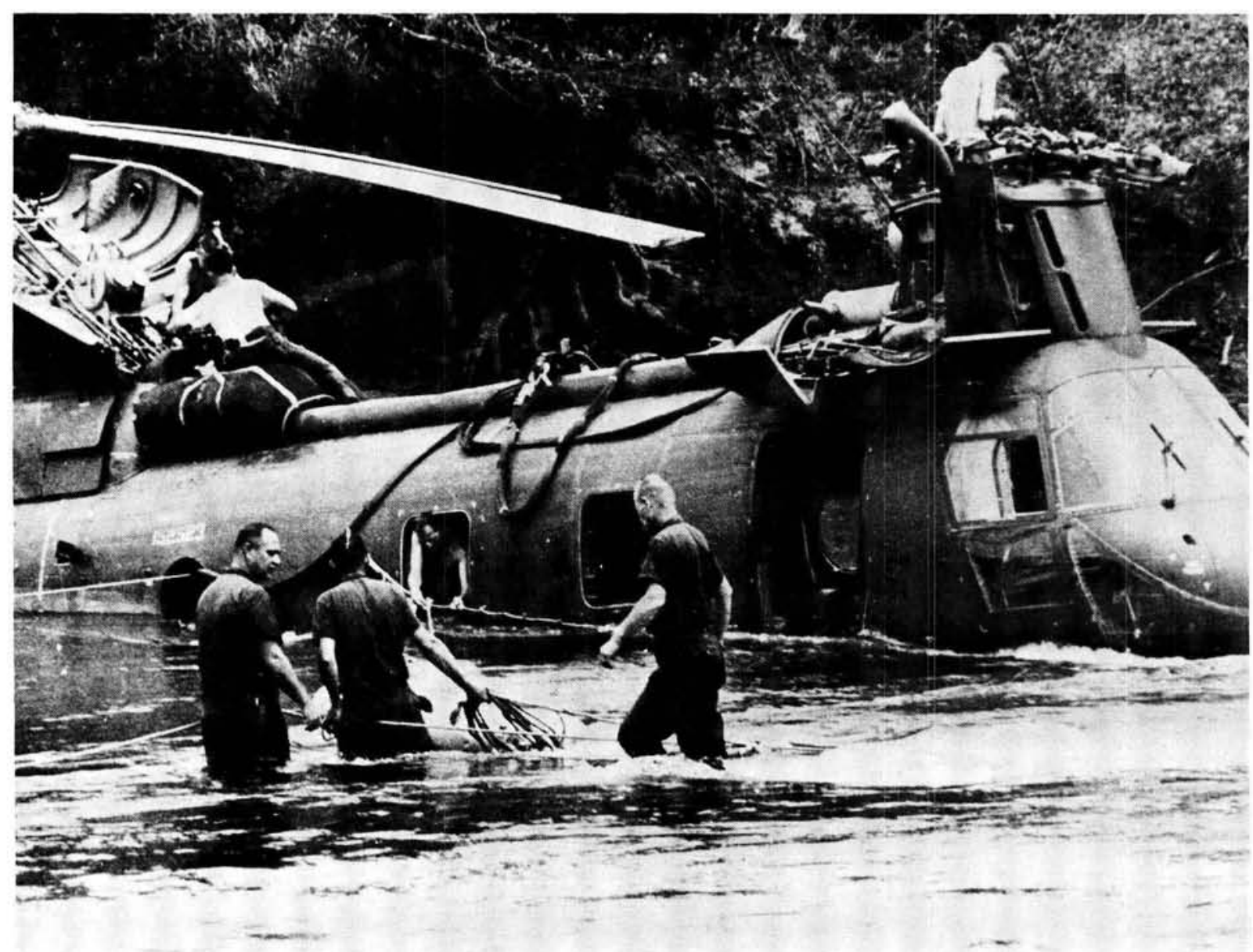

Kapt James F. Pleva (VSA) se Sea Knight het aan die brand geslaan nadat dit deur vyandelike vuur getref is maar hy kon homself en die helikopter red deur in 'n bergstroom te land. Die helikopter is herwin.

(Foto: Bern Keating, 'Chopper!' 1976)

word: 'These forces may be assigned various tasks: delay the entry of the enemy's reserves; destroy nuclear attack weapons; occupy and hold (until the arrival of advance units), water crossings and sections suitable for crossing in force; destroy command posts in the rear, hold mountain passes, gorges, road intersections, and other important tactical areas or facilities of the enemy. In addition, they can seize sections of a shoreline and thus contribute to the landing of marines. ${ }^{25}$

Ten slotte dien vermeld te word dat die 'helitroep' in teenstelling met die valskermsoldaat, heelwat meer uitrusting en ammunisie kan saamneem en terugbring.

Die aanwending van helikopters in lugtransportoperasies hou egter wel nadele in wat nie uit die oog verloor mag word nie. Die helikopter se vliegradius is relatief kort terwyl sy aanwending op die slagveld tot in ' $n$ hoë mate deur beheer oor die aangrensende gebied bepaal word. ${ }^{26}$ Verder moet in gedagte gehou word dat die helikopter ' $n$ duur en terselfdertyd ' $n$ uiters kwesbare item is wat gewoonlik selde onafhanklik kan opereer. Waar vastevlerkvliegtuie slegs tydens die oorvlugfase binne die skootveld van vyandelike lugafweergeskut beweeg, moet die helikopter 'n landing uitvoer en dus noodwendig nader aan die grond beweeg. Voeg hierby die feit dat dit vir 'n kort periode staties op die grond is wat dit 'n maklike teiken vir vyandelike vuur maak.

Die toekomstige rol van die transporthelikopter in konvensionele oorlogvoering sal grootliks bepaal word deur tegnologiese ontwikkeling op lugvaartgebied. Oor sy belang as logistieke medium in ' $n$ ondersteuningsrol kan nouliks getwyfel word maar wat sy operasionele aanwending in die konfliksituasie betref, is heersende menings en beskouings hoogstens spekulatief. In die futuristiese scenario World War 3 word 'n geringe rol aan die transporthelikopter toegeken; hiervolgens sal helikopters in die Lynx-reeks gebruik work vir klein vegspanne se taktiese aanwending. ${ }^{27}$ Hierdie beskouing stem feitlik ooreen met dié van sir John Hackett wat die helikopter hoofsaaklik as lugmobiele geskut tipeer. ${ }^{28}$ 
Volgens Britse doktrine is die helikopter se aanwending grootliks beperk tot 'n noue ondersteuningsrol in valskermoperasies. ${ }^{29}$ Die Amerikaners huldig ' $n$ meer revolusionêre siening die helikopter is 'n hoogs mobiele wapen en behoort waar en wanneer en op enige paslike wyse soos die opperbevel dit goed dink, aangewend te word. Die Amerikaanse beskouing is egter gebaseer op een belangrike voorvereiste, $\mathrm{nl}$ dat die transporthelikopter in nagtoestande moet kan opereer..$^{30}$ Wat die Franse betref, is enige standpunt oor helikopters 'une fausse guerelle' (nie ter sake!). Die Franse siening is kortweg dat die helikopter op enige terrein kan opereer solank dit kan bydra tot die oplos van bevels- en logistiese probleme. Troepeformasies moet in staat wees om snags op te tree. Die ander Navolande beskou die helikopter enersyds as 'n lugwapen vir tenkafweer en andersyds as 'n implement vir defensiewe oorlogvoering.

Ofskoon die USSR tot op hede lugtransportoperasies dmv helikopters nie so belangrik as die VSA beskou nie, is daar nietemin aanduidings dat die Russe reeds die waarde van lugmobiele eenhede besef. Volgens ingeligte bronne word in Sowjetkringe reeds gedink aan lugmobiele eenhede of taakmagte op divisie- en bataljonsvlak wat oor ' $n$ wye front kan opereer. ${ }^{31}$

Hoewel veel gewag gemaak word van die aanwending van die transporthelikopter in onkonvensionele oorlogvoering en spesiale operasies, wil dit tog voorkom dat transporthelikopters steeds ' $n$ belangrike rol het om te vervul in konvensionele konflikte. Of die ander groot moondhede die voorbeeld van die VSA en die USSR gaan volg, bly egter ' $n$ groot vraag.

\footnotetext{
- Kmdt C. J. Nöthling, MA is verbonde aan die Militêre Informasie buro van die SAW.

- Met bostaande artikel het kmdt Nöthling die Eerste Prys verwerf in die Militêre Opstelwedstryd van 1980.
}

Verwysings:

1. ANON, 'The Helicopter in Modern Combat', Military Technology Vol 3 No 7, Jan/Feb 1979, p 9.

2. LAMBERT, Mark, 'Battlefield Helicopters', Flight International Vol 115 No 3646, Feb 1979, p 319. Die skrywer meld onder meer dat NAVO teen 1985 bykans 2000 taktiese helikopters op sterkte in Europa sal hê.

3. D TAAL, SAW, Gesamentlike Operasionele Woordeboek, 1978, p 412 : Vertikale omsingeling word omskryf as 'n 'taktiese maneuver waarby lugvervoerde troepe, hetsy per valskerm, of uit die lug geland, die agterhoede en flanke van 'n mag aanval en sodoende dit afsny of omsingel.' Vertikale omsingeling sowel as snelle ontplooiing is fundamentele beginsels van moderne oorlogvoering en is reeds in die Tweede Wêreldoorlog deur die magte van die Spil- en Geallieerde moondhede met welslae as verskillende vorme van die Blitzkrieg toegepas.

4. HOLLINGWORTH, Franklin Gregory, The Helicopter, Barnes, Cranbury 1976, pp 22-23.

5. Ibid.

6. MONTROSS, Lynn, Cavally of the Sky, Harper, New York 1954, p 57.

7. GABLEHOUSE, Charles, Helicopters and Autogiros, Frederick Muller, Londen 1968, p 125.

8. MONTROSS, Lynn, op cit, p 221.

9. GABLEHOUSE, C., op cit, $p 126$

10. LITTAUER, R. en Norman Uphoff (reds), The Air War in Indochina, Beacon, Boston 1972, pp 212-213.

11. HORGAN, E. J., 'Blitzkrieg', An Cosantoir, Mei 1977, p 159.

12. BONDS, Ray, The Soviet War Machine, Hamlyn, Londen 1976, p 168

13. TAYLOR, John W. R., Jane's all the World's Aircraft 1977-1978, Londen 1978, p 339.

14. HEISER, Joseph M., Vietnam Studies : Logistic Support, Dept of US Army, Washington D.C. 1974, p 219.

15. Ibid, p 154.

16. HOLLINGSWORTH, F. G., op cit, $p 168$.

17. GABLEHOUSE, C., op cit, $p 121$.

18. D TAAL, SAW, op cit, op cit, $p$ 165. Die hoofaanval word omskryf as die 'aanval of bydrae waarvoor die bevelvoerder die volle gewig van die offensiewe mag tot sy beskikking gebruik: aanval wat teen die hoofdoelwit van die veldtog of geveg gerig word.'

19. PRICE, David H., 'The Army Aviation Story (12) : The Late 1960s', US Army Aviation Digest August 1976, p 21.

20. TUGWELL, Maurice, Arnhem : A Case Study, Thornton Cox, Londen 1975. 21. DEVLIN, Gerard M., Paratrooper, St Martin's, New York 1979, pp
222-226.

22. TUGWELL, Maurice A. J., 'Day of the Paratroops', Military Review Mrt 1977, p 40.

23. TUGWELL, M. A. J., ibid, p 51.

24. TURBIVILLE, Graham H., 'A Soviet View of Heliborne Assualt Operations', Military Review Okt 1975, p 6: 'But perhaps the main distinction of the helicopter landing is that personnel who have been trained for just a few hours can be used in it."

25. Ibid, $p$ 6 .

26. LITTAUER, R. en N. Uphoff, op cit, $p 7$

27. BIDWELL, Shelford, et al, World War 3, Prentice Hall, New York 1978, pp 157-158.

28. HACKET,, Sir John, et al, The Third World War, Sidgwick en Jackson, Londen 1978, p 181

29. LAMBERT, Mark, 'Germany's Military Helicopter Meet', Flight International Vol 113 No 3611,3 Jun 1978, p 1693.

30. Ibid, p 1694

31. TURBIVILLE, G. H., op cit, pp 15-16. 